\title{
Funkcionalna vrijednost i nutritivni potencijal proizvoda planike (Arbutus unedo L.)
}

\author{
Functional value and nutritional potential of plantain products \\ (Arbutus unedo L.) \\ Jana Šic Žlabur, Martina Skendrović Babojelić, A. Galić, Sandra Voća
}

\section{SAŽETAK}

Cilj ovog istraživanja bio je utvrditi fizikalno-kemijska svojstva, sadržaj bioaktivnih spojeva i nutritivni potencijal dvaju proizvoda planike: džema i vodene infuzije listova. Način pripreme džema varira postupkom pasiranja: nepasirani (NP1) i pasirani džem (P2). Džem tretmana NP1 imao je značajno viši sadržaj ukupne i topljive suhe tvari te višu $\mathrm{pH}$ - vrijednost u usporedbi s P2. Također, tretman pasiranja utjecao je i na promjenu boje gotovog proizvoda prilikom čega je za džem P2 utvrđeno svjetlije crveno, a džem NP1 tamnije crveno obojenje. Postupak pasiranja pridonio je povećanju sadržaja pojedinih bioaktivnih spojeva u P2, prilikom čega je u džemu tretmana P2 utvrđen $17 \%$ viši sadržaj vitamina $C$, značajno viši sadržaj polifenolnih spojeva kao i viši antioksidacijski kapacitet u usporedbi s NP1. No, oko 3 puta viši sadržaj $\beta$-karotena utvrđen je u NP1 džemu. Također, iz analize vodene infuzije listova vidljiv je visok sadržaj bioaktivnih spojeva, a posebice ukupnih fenola (715,79 mg GAE/100 g svježe tvari). Temeljem svega, može se zaključiti kako oba proizvoda obične planike pokazuju visok nutritivni potencijal i značajnu funkcionalnu vrijednost, a time predstavljaju zdravstveno vrijedne proizvode široke mogućnosti upotrebe.

Ključne riječi: džem, vodena infuzija listova, vitamin $C$, ukupni fenoli, $\beta$-karoten, antioksidacijski kapacitet

\begin{abstract}
The aim of this research was to determine the physical and chemical parameters, content of bioactive compounds and nutritional potential of two strawberry tree products: jam and leaves water infusion. The method of jam preparation was varied by straining/mashing: non-strained (NP1) and strained (P2) jam samples. Jam prepared by NP1 treatment had a significantly higher total dry matter content, total soluble solids and $\mathrm{pH}$-value compared to the $\mathrm{P} 2$ jam. Also, straining/mashing treatment affected the color change of final product, which in brighter red color was determined for P2 jam, while darker red coloration described NP1 jam. Straining treatment contributed to the increase of the bioactive compounds content in $\mathrm{P} 2$, where a $17 \%$ higher vitamin $\mathrm{C}$ content was determined as well as a higher total polyphenol content and a higher
\end{abstract}


Jana Šic Žlabur i sur.: Funkcionalna vrijednost i nutritivni potencijal proizvoda planike (Arbutus unedo L.)

antioxidant capacity compared to the NP1 jam. However, a three-fold higher $\beta$-carotene content was determined in NP1 jam. From chemical analysis of leaves water infusion, a high content of bioactive compounds, especially total phenols (715,79 mg GAE/100 g fresh weight), is noticeable. Based on all above-mentioned, it can be concluded that both strawberry tree products show a high nutritional potential and a significant functional value, thus representing health-valuable products with a wide range of uses.

Key words: jam, leaves water infusion, vitamin $\mathrm{C}$, total phenols, $\beta$-carotene, antioxidant capacity

\section{UVOD}

Obična planika (Arbutus unedo L.), u Hrvatskoj poznatija pod nazivima jagodnjak ili maginja, voćna je vrsta iz roda Arbutus široko rasprostranjena kao samonikla u pojasu eumediteranske zone (vazdazelena vrsta) prilikom čega $u$ Europi raste $\mathrm{u}$ cijelom mediteranskom bazenu, od Portugala do Turske uključujući i mediteranske otoke. U Hrvatskoj je obična planika samonikla voćna vrsta rasprostranjena od Istre do Konavala prilikom čega joj prirodna staništa predstavljaju šumoviti krajevi, mediteranske šume i makije (Oliveira i sur., 2011.; Skendrović Babojelić i sur., 2020.). Obična planika je u Hrvatskoj zapostavljena voćna vrsta, odnosno njezin potencijal uzgoja kao i konzumacije nije dovoljno iskorišten. U mediteranskim zemljama razvijenog voćarstva, poput Španjolske ili Italije, intenzivno se uzgaja i koristi za preradu u različite proizvode. Naime, plod i list planike posjeduju značajne funkcionalne vrijednosti te mnoga istraživanja dokazuju izrazito visok sadržaj minerala, lako probavljivih šećera, prehrambenih vlakana, vitamina (posebice vitamina C) kao i brojnih drugih bioaktivnih spojeva značajne antioksidacijske aktivnosti (Miguel i sur., 2014.). Zbog navedenog bogatog kemijskog sastava, u posljednje vrijeme sve je više popularizirana u konzumaciji, prvenstveno zbog povoljnog nutritivnog sastava i ljekovitih svojstava: djeluje kao antiseptik, diuretik, laksativ, ima protuupalno djelovanje, pomaže u prevenciji dijabetesa i dr. (RuizRodriguez i sur., 2011.; Barros i sur., 2010.; Gündoğdu i sur., 2018.). Plod obične planike specifičan je po načinu dozrijevanja prilikom čega svi plodovi ne dozrijevaju istovremeno pa se na istom stablu mogu naći plodovi različitog stupnja obojenja, a time i različitog sastava pigmentnih spojeva (karotenoidi, antocijani), također važnih antioksidansa (Barros i sur., 2010.; Miguel i sur., 2014.). Plodovi zbog visokog sadržaja ugljikohidrata nisu toliko cijenjeni za konzumaciju u svježem stanju, a i brzo fermentiraju, pa se i iz zdravstvenog aspekta ne preporuča njihova pretjerana konzumacija (Gündoğdu i sur., 2018.). Upravo zbog navedenog, plodovi se češće koriste u proizvodnji alkoholnih pića 
poput vina i likera, prerađuju se u džemove ili koriste kao dodatak u proizvodnji voćnih jogurta, nadjeva u pekarskoj proizvodnji, proizvoda od žitarica i sličnih (Ayaz i sur., 2000.; Soufleros i sur., 2005.). Zanimljivo je i da listovi biljke predstavljaju nutritivno vrijednu sirovinu prilikom čega istraživanja dokazuju visok sadržaj vitamina $\mathrm{C}$ i specifičnih fitonutrijenata poput polifenolnih spojeva (arbutin), terpenoida, esencijalnih ulja, tokoferola i dr. (Maleš i sur., 2005.; Pavlović i sur., 2009.). Temeljem navedenog, uporaba listova i proizvodi lista planike poput infuzije (vodenog pripravka) pokazuju brojna biološka svojstva od značajne antioksidacijske aktivnosti (Malheiro i sur., 2012.), antibakterijskog i antifungalnog učinka (Ferreira i sur., 2012.) do protuupalnog djelovanja (Mariotto i sur., 2008.).

Cilj ovog istraživanja bio je utvrditi fizikalno-kemijska svojstva, sadržaj bioaktivnih spojeva i nutritivni potencijal dvaju proizvoda planike: džema $\mathrm{i}$ vodene infuzije listova.

\section{MATERIJAL I METODE}

Biljni materijal

Plodovi obične planike samoniklih jedinki sakupljeni su u studenom 2019. godine u stadiju potpune zrelosti većine plodova, procijenjene temeljem vanjske boje plodova, prilikom čega je većina bila narančaste do tamnocrvene boje. Plodovi su ubrani na području Rovinja (Istra), na lokacijama Monsena

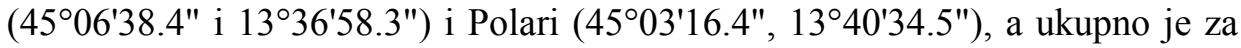
potrebe istraživanja uzorkovano po 40 plodova u tri repeticije (svako stablo s iste lokacije predstavljalo je jednu repeticiju). Prilikom ubiranja plodova, sakupljeni su i listovi koji su otkidani bez peteljke (40 listova u tri repeticije). Odmah nakon ubiranja, sakupljeni biljni materijal (plodovi i listovi) transportiran je do laboratorija Zavoda za poljoprivrednu tehnologiju, skladištenje i transport pri Agronomskom fakultetu Sveučilišta u Zagrebu gdje su u plastičnim posudama ostavljeni u rashladnom prostoru $\left(4^{\circ} \mathrm{C}\right)$ do pripreme pojedinih proizvoda.

\section{Priprema džema}

Za potrebe pripreme džema, prikupljeni plodovi prvo su probrani, odnosno odstranjeni su oni s eventualnim oštećenjima ili znakovima kvarenja, zatim su oprani u higijensko i zdravstveno ispravnoj vodi te prosušeni. Plodovi su nakon toga homogenizirani laboratorijskim homogenizatorom u kašu te je dio voćne kaše odvojen za pasiranje (pasirani džem), dok je drugi dio pripremljen za 
ukuhavanje bez prethodnog pasiranja (nepasirani džem). Pasiranje je provedeno $\mathrm{u}$ svrhu uklanjanja karakterističnih papila s površine ploda koji zajedno sa sjemenkama iz unutrašnjosti ploda zaostaju u finalnom proizvodu, a u kojem nisu poželjni zbog otežane konzumacije.

Prilikom pripreme džema prethodno je izvagana voćna kaša na čiju je masu dodano ukupno $30 \%$ konzumnog šećera (saharoze). Postupak pripreme džema uključivao je zagrijavanje voćne kaše do vrenja, dodatak spomenute količine šećera i ukuhavanja do željene gustoće odnosno konzistencije proizvoda. Važno je naglasiti da svježi plodovi planike u stadiju potpune zrelosti sadrže veću količinu ugljikohidrata te nije potrebno dodavanje veće količine šećera. Isti postupak korišten je i za pripremu pasiranog džema uz razliku što je voćna kaša prije ukuhavanja propasirana u svrhu uklanjanja papila, dijelova kožice i sjemenki iz unutrašnjosti ploda. Dobiveni džem odmah nakon ukuhavanja punjen je u prethodno steriliziranu staklenu ambalažu i ostavljen na sobnoj temperaturi da se ohladi za potrebe provođenja kemijskih analiza.

Priprema vodene infuzije listova

Listovi su prije pripreme infuzije probrani, odstranjeni su oni s eventualnim oštećenjima i usitnjeni. Odvagano je 3 g usitnjenih listova u staklenu laboratorijsku čašu, dodano $150 \mathrm{~mL}$ vruće destilirane vode $\left(100^{\circ} \mathrm{C}\right)$ i ostavljeno 10 minuta pri sobnoj temperaturi. Nakon ekstrakcije infuzija je filtrirana preko običnog Whatmanovog filter papira za potrebe uklanjanja listova. Bistra vodena infuzija listova korištena je za potrebe kemijskih analiza.

Metode određivanja fizikalno-kemijskih svojstava džema i vodene infuzije

Za potrebe određivanja fizikalno-kemijskih svojstava, standardnim laboratorijskim metodama provedene su sljedeće kemijske analize: sadržaj ukupne suhe tvar (ST, \%) sušenjem do konstantne mase pri $105^{\circ} \mathrm{C}$ (AOAC, 1995.), sadržaj topljive suhe tvari (TST, \%) izravnim očitanjem s digitalnog refraktometra (Mettler Toledo, Refracto 30PX, Švicarska), sadržaj ukupnih kiselina (UK_KIS, \%) potenciometrijskom titracijom (AOAC, 1995), pH-vrijednost pomoću pH-metra (Mettler Toledo, SevenMulti, Švicarska). Također, određena je i boja gotovih proizvoda ručnim kolorimetrom (ColorTec $\mathrm{PCM}+$, Kina) CIELAB metodom. Boje uzoraka proizvoda od planike opisane su pomoću brojčane vrijednosti: $L^{*}, a^{*}$ i $b^{*}$ uz prikazanu $h^{\circ}$ vrijednost (vizualni doživljaj, ton boje) i $C^{*}$ vrijednost (zasićenost boje). 
Jana Šic Žlabur i sur.: Funkcionalna vrijednost i nutritivni potencijal proizvoda planike (Arbutus unedo L.)

Metode određivanja bioaktivnih spojeva i antioksidacijskog kapaciteta

Iz skupine bioaktivnih spojeva određen je sadržaj sljedećih nutrijenata: vitamina $\mathrm{C}(\mathrm{mg} / 100 \mathrm{~g}$ gotovog proizvoda) titracijom s 2,6-diklorindofenolom prema AOAC (2002.), sadržaj ukupnih fenolnih spojeva (uključujući flavonoide i neflavonoide, mg GAE/100 g gotovog proizvoda) spektrofotometrijski (Shimadzu, UV 1650 PC) kolorimetrijskom metodom koja se temelji na obojenoj reakciji koju fenoli razvijaju s Folin-Ciocalteovim reagensom (Ough i Amerine, 1988) i sadržaj $\beta$-karotena $(\mu \mathrm{g} / 100 \mathrm{~g})$ spektrofotometrijski (Shimadzu, UV 1650 PC) prema metodi koju je opisao Booth (1957.). Antioksidacijski kapacitet određen je spektrofotometrijski uz upotrebu ABTS radikala kationa [2,2'-azinobis (3-etilbenzotiazolin-6-sulfonska kiselina)] (Re i sur., 1999.).

\section{Statistička analiza}

Uzorci džema (pasirani i nepasirani) kao i vodena infuzija listova pripremljeni su u tri repeticije $(\mathrm{n}=3)$, a sve laboratorijske analize kemijskih parametara su također provedene u tri ponavljanja. Statistička analiza podataka provedena je za potrebe usporedbe uzoraka džemova prilikom čega je korištena jednosmjerna analiza varijance (ANOVA), a srednje vrijednosti su uspoređene LSD testom pri čemu je $\mathrm{P}=1 \%$ smatrana statističkim pragom značajnosti. Uz rezultate u tablicama prikazana su različita slova koja označavaju značajne statističke razlike između variranih tretmana kod $p \leq 0,0001$. Prikazano je $i$ prosječno odstupanje rezultata od srednje vrijednosti za svaki istraživani kemijski parametar vrijednostima standardne devijacije.

\section{REZULTATI I RASPRAVA}

Fizikalno-kemijska svojstva džema planike

U Tablici 1. prikazana su analizirana osnovna kemijska svojstva uzoraka džemova planike. Prema dobivenim rezultatima statističke analize, nepasirani (NP1) i pasirani (P2) džem planike značajno se statistički razlikuju u svim istraživanim svojstvima, a prilikom čega tretman NP1 ima značajno viši sadržaj suhe tvari (ST), topljive suhe tvari (TST) i pH-vrijednosti u usporedbi $\mathrm{s}$ tretmanom P2, dok istovremeno navedeni uzorak ima nižu vrijednost ukupnih kiselina (UK_KIS) u usporedbi s P2. Dobiveni rezultati s obzirom na varirani tretman su očekivani. Naime, postupkom pasiranja izdvajaju se pojedini dijelovi ploda planike (papile, sjemenke), što u konačnici utječe na smanjenje sadržaja 
ST i TST. U P2 viši sadržaj UK_KIS također je posljedica postupka pasiranja prilikom čega su se prirodno prisutne organske kiseline ploda postupkom pasiranja lakše otopile u izdvojenom staničnom soku, odnosno voćnoj kaši korištenoj za pripremu džema. Prema važećem Pravilniku o voćnim džemovima, želeima, marmeladama, pekmezu te zaslađenom kesten pireu (NN, 84/19), oba uzorka džema planike (NP1, P2) imaju sadržaj suhe tvari viši od 60 $\%$ te ih se može klasificirati u kategoriju proizvoda „džem“. Također, relativno visok sadržaj TST, koji predstavlja ukupni sadržaj ugljikohidrata u voćnoj sirovini, očekivan je i s obzirom na dodanu količinu šećera u postupku pripreme džema, ali i na to da je plod planike u svježem stanju karakterističan po visokom sadržaju šećera poput glukoze, fruktoze, saharoze i maltoze (Vidrih i sur., 2013). Dobiveni rezultati sadržaja UK_KIS u oba uzorka džema podudaraju se s vrijednostima sadržaja ukupnih kiselina iz drugih literaturnih navoda (Morales i sur., 2013), a prilikom čega drugi autori od zastupljenijih organskih kiselina ploda planike navode fumarnu, mliječnu, jabučnu, suberinsku i limunsku kiselinu (Ruiz-Rodriguez i sur., 2011).

Tablica 1. Osnovni kemijski sastav džema planike

Table 1 Basic chemical composition of strawberry tree jam

\begin{tabular}{|l|c|c|c|c|}
\hline \multicolumn{1}{|c|}{ Tretman } & ST (\%) & TST (\%) & UK_KIS (\%) & $\mathrm{pH}$ \\
\hline NP1 & $69,01 \mathrm{a} \pm 0,39$ & $57,07 \mathrm{a} \pm 0,06$ & $0,79 \mathrm{~b} \pm 0,006$ & $3,24 \mathrm{a} \pm 0,01$ \\
\hline P2 & $66,88 \mathrm{~b} \pm 0,09$ & $51,67 \mathrm{~b} \pm 0,12$ & $0,88 \mathrm{a} \pm 0,006$ & $3,17 \mathrm{~b} \pm 0,01$ \\
\hline ANOVA & $\mathrm{p} \leq 0,0008$ & $\mathrm{p} \leq 0,0001$ & $\mathrm{p} \leq 0,0001$ & $\mathrm{p} \leq 0,0006$ \\
\hline
\end{tabular}

ST- ukupna suha tvar; TST- topljiva suha tvar; UK_KIS- ukupne kiseline

Od fizikalnih svojstava džema planike istraživani su kromatski parametri, odnosno boja gotovog proizvoda (Tablica 2.). Sve analizirane vrijednosti kromatskih parametara $\left(L^{*}, a^{*}, b^{*}, C^{*}\right.$ i $\left.h^{\circ}\right)$ značajno se statistički razlikuju $\mathrm{s}$ obzirom na tretman pripreme džema. Iz dobivenih $L^{*}$ vrijednosti vidljivo je kako džem P2 pokazuje više vrijednosti, a što upućuje na svjetliju boju uzorka s obzirom da kromatski parametar $L^{*}$ označava intenzitet svjetla ili tame te ukoliko je vrijednost $L^{*}=0$ tada nema refleksije što upućuje na prisutnost crne boje, a ako je $L^{*}=100$ refleksija je najveća i radi se o bijeloj boji. Kromatski parametar $a^{*}$ označava intenzitet crvene (pozitivne vrijednosti) ili zelene boje (negativne vrijednosti), parametar $b^{*}$ označava intenzitet žute (pozitivne vrijednosti) ili plave boje (negativne vrijednosti), dok $C^{*}$ i $h^{\circ}$ vrijednosti s kromatskog dijagrama označavaju zasićenost boje ( $C^{*}$ vrijednost) te ton boje 
Jana Šic Žlabur i sur.: Funkcionalna vrijednost i nutritivni potencijal proizvoda planike (Arbutus unedo L.)

( $h^{\circ}$ vrijednost). Za džemove PN1 i P2 utvrđene su pozitivne $a^{*}$ i $b^{*}$ vrijednosti (crveni spektar), a s obzirom na varirani tretman općenito je utvrđeno da je džem NP1 tamnije crvene boje. Temeljem svega, može se zaključiti da je tretman pasiranja prilikom pripreme džema utjecao na promjenu boje gotovog proizvoda; P2 je svjetlije crvenog, a PN1 tamnije crvenog obojenja, što je i očekivano $\mathrm{s}$ obzirom da se pasiranjem uklanjaju vanjski dijelovi ploda planike (papile i kožica) u kojima su koncentrirane veće količine pigmenata poput antocijanina (Pimpão i sur., 2013).

Tablica 2. Vrijednosti kromatskih parametara uzoraka džema planike

Table 2 Chromaticity parameters of strawberry tree jams

\begin{tabular}{|l|c|c|c|c|c|}
\hline Tretman & $L^{*}$ & $a^{*}$ & $b^{*}$ & $C^{*}$ & $h^{\circ}$ \\
\hline NP1 & $21,02 \mathrm{~b} \pm 1,48$ & $19,99 \mathrm{a} \pm 0,18$ & $13,56 \mathrm{~b} \pm 1,74$ & $24,18 \mathrm{~b} \pm 1,02$ & $34,06 \mathrm{~b} \pm 3,41$ \\
\hline P2 & $31,36 \mathrm{a} \pm 1,37$ & $15,69 \mathrm{~b} \pm 1,33$ & $27,39 \mathrm{a} \pm 2,35$ & $31,57 \mathrm{a} \pm 2,44$ & $60,02 \mathrm{a} \pm 1,73$ \\
\hline ANOVA & $\mathrm{p} \leq 0,0009$ & $\mathrm{p} \leq 0,0052$ & $\mathrm{p} \leq 0,0069$ & $\mathrm{p} \leq 0,0283$ & $\mathrm{p} \leq 0,0003$ \\
\hline
\end{tabular}

Sadržaj bioaktivnih spojeva i antioksidacijski kapacitet džema i vodene infuzije listova planike

Bioaktivni (sekundarni) metaboliti karakteristični su fitonutrijenti (vitamini, polifenolni spojevi, pigmenti i dr.) značajnog biološkog potencijala, čime ih se ubraja u skupinu biološki aktivnih spojeva (Šic Žlabur i sur., 2018). Navedeni spojevi ponajviše se ističu snažnim antioksidacijskim djelovanjem, zbog čega pokazuju izrazitu važnost za ljudsko zdravlje (Pott i sur., 2019.). Svježi plod, ali i list obične planike bogat su izvor bioaktivnih spojeva (Miguel i sur., 2014.), prema čemu je očekivano da i njihovi proizvodi pokazuju povoljan nutritivan sastav. Prema rezultatima ovog istraživanja, zanimljivo je kako džem planike sadrži izrazito visok sadržaj vitamina C (prosječno 198,17 mg/100 g gotovog proizvoda) (Tablica 3.), usprkos tomu što postupak pripreme džema pretpostavlja duži vremenski period ukuhavanja pri visokim temperaturama $\left(\sim 90{ }^{\circ} \mathrm{C}\right)$, a što značajno utječe na degradaciju termolabilnog vitamina $\mathrm{C}$. Također, utvrđeno je kako tretman pripreme džema značajno utječe $(\mathrm{p} \leq 0,0001)$ na sadržaj vitamina C prilikom čega je u P2 utvrđen značajno viši sadržaj (17 $\%$ ) u odnosu na NP1. Vitamin C je u vodi topljiv vitamin što sugerira kako je postupak pasterizacije dodatno doprinio njegovom otapanju u staničnom soku, voćnoj kaši koja je ukuhavana. Isto tako, viši sadržaj ukupnih fenolnih spojeva i neflavonoida utvrđen je u P2 u usporedbi s NP1. Općenito, oba džema planike 
Jana Šic Žlabur i sur.: Funkcionalna vrijednost i nutritivni potencijal proizvoda planike (Arbutus unedo L.)

sadrže visok sadržaj ukupnih fenolnih spojeva (neovisno o tretmanu prosječno 482,54 mg GAE/100 g gotovog proizvoda), uključujući i neflavonoide (prosječno 243,69 mg GAE/100 g gotovog proizvoda) i flavonoide $(238,85 \mathrm{mg}$ GAE/100 g gotovog proizvoda), što se poklapa i s drugim literaturnim navodima koji ističu planiku kao voćnu vrstu bogatog polifenolnog profila, od fenolnih kiselina, flavonola, flavan-3-ola, derivata galola do antocijanidina (Pimpão i sur., 2013.). Od pigmentnih spojeva, u džemu planike je analiziran sadržaj $\beta$-karotena $\mathrm{s}$ obzirom da i literaturni navodi ističu kako plod planike sadrži i razne spojeve iz skupine karotenoida poput: $\beta$-karotena, značajno viši sadržaj $\beta$-karotena (oko 3 puta) utvrđen je u NP1 u usporedbi s P2. Temeljem utvrđenih visokih vrijednosti svih analiziranih bioaktivnih spojeva, determiniran visok antioksidacijski kapacitet oba uzorka džema (Tablica 3.) je očekivan. Tretman pripreme je utjecao na antioksidacijski kapacitet, a tretman NP1 pokazuje nešto niže vrijednosti u odnosu na P2. Navedeni trend je očekivan s obzirom na pozitivnu korelaciju, odnosno pozitivan utjecaj biološki aktivnih spojeva na antioksidacijsku aktivnost: uzorci koji imaju viši sadržaj bioaktivnih spojeva pokazuju i višu antioksidacijsku aktivnost (Šic Žlabur i sur., 2016.).

Pripremljena vodena infuzija listova također pokazuje bogat sastav pojedinih analiziranih bioaktivnih spojeva (Tablica 3). Kao što je navedeno, i list planike izrazito je dobar izvor vitamina $C$, polifenolnih spojeva i klorofilnih pigmenata (Maleš i sur., 2013.), a time i vodena infuzija listova predstavlja vrijedan izvor i značajan nutritivni potencijal. Valja izdvojiti izrazito visok sadržaj ukupnih fenolnih spojeva (715,79 $\mathrm{mg}$ GAE/100 $\mathrm{g}$ infuzije), a time i visok antioksidacijski kapacitet (1,76 mmol TE/L).

Tablica 3. Sadržaj bioaktivnih spojeva i antioksidacijski kapacitet džemova i vodene infuzije listova planike

Table 3 Content of bioactive compounds and antioxidant capacity of strawberry tree jam and leaves water infusion

\begin{tabular}{|l|c|c|c|c|c|c|}
\hline Tretman & $\begin{array}{c}\text { Vit_C } \\
(\mathrm{mg} / 100 \mathrm{~g} \text { sv })\end{array}$ & $\begin{array}{c}\text { FENOLI } \\
(\mathrm{mgGAE} / \\
100 \mathrm{~g} \mathrm{sv})\end{array}$ & $\begin{array}{c}\text { NFLV } \\
(\mathrm{mgGAE} / \\
100 \mathrm{~g} \text { sv })\end{array}$ & $\begin{array}{c}\text { FLAV } \\
(\mathrm{mgGAE} / \\
100 \mathrm{~g} \mathrm{sv})\end{array}$ & $\begin{array}{c}\beta \text {-karoten } \\
(\mu \mathrm{g} / 100 \mathrm{~g} \mathrm{sv})\end{array}$ & $\begin{array}{c}\text { ANT_KAP } \\
(\mathrm{mmol} \\
\text { TE/kg) }\end{array}$ \\
\hline \multicolumn{7}{|c|}{ Džem } \\
\hline NP1 & $182,70 \mathrm{~b} \pm 0,5$ & $476 \mathrm{~b} \pm 0,05$ & $222,23 \mathrm{~b} \pm 0,5$ & $253,77 \mathrm{a} \pm 0,3$ & $347,92 \mathrm{a} \pm 0,6$ & $1,74 \mathrm{~b} \pm 0,1$ \\
\hline P2 & $213,64 \mathrm{a} \pm 0,6$ & $489,07 \mathrm{a} \pm 0,7$ & $265,14 \mathrm{a} \pm 0,3$ & $223,92 \mathrm{~b} \pm 0,7$ & $111,69 \mathrm{~b} \pm 0,4$ & $1,77 \mathrm{a} \pm 0,1$ \\
\hline ANOVA & $\mathrm{p} \leq 0,0001$ & $\mathrm{p} \leq 0,0001$ & $\mathrm{p} \leq 0,0001$ & $\mathrm{p} \leq 0,0001$ & $\mathrm{p} \leq 0,0001$ & $\mathrm{p} \leq 0,0001$ \\
\hline \multicolumn{7}{|c|}{ Infuzija listova } \\
\hline
\end{tabular}

Vit_C- vitamin C; NFLV- neflavonoidi; FLAV- flavonoidi; ANT_KAP- antioksidacijski kapacitet 
Jana Šic Žlabur i sur.: Funkcionalna vrijednost i nutritivni potencijal proizvoda planike (Arbutus unedo L.)

\section{ZAKLJUČAK}

Prema dobivenim rezultatima, oba analizirana proizvoda obične planike (džem i vodena infuzija listova) bogati su sadržajem bioaktivnih spojeva, posebice vitamina $\mathrm{C}$ i fenolnih spojeva, te kao takvi pokazuju značajan nutritivni potencijal i visoku funkcionalnu vrijednost. Način tretmana prilikom pripreme džema utjecao je na sva istraživana fizikalno-kemijska svojstva i sadržaj bioaktivnih spojeva, prilikom čega se može sugerirati primjena postupka pasiranja prije ukuhavanja u džem jer tako pripremljen gotov proizvod pokazuje bolja nutritivna svojstva. Također, osim ploda i list se može koristiti u konzumaciji, a prvenstveno u zdravstvene svrhe na što sugeriraju i rezultati ovog istraživanja s obzirom da je u vodenoj infuziji listova planike utvrđen izrazito visok sadržaj ukupnih fenolnih spojeva i visok antioksidacijski kapacitet. Upotreba svježeg ploda kao i proizvoda obične planike značajno su zanemareni na području Hrvatske te rezultati ovog istraživanja mogu pridonijeti popularizaciji navedene voćne vrste i njenih proizvoda.

\section{Zahvala}

Istraživanje je provedeno u sklopu projekta „Selekcija i kemotipizacija prirodnih populacija planike s područja Istre i Dalmacije“ (2017. - 2020.) kojeg je financirala Zaklada Adris.

\section{LITERATURA}

AOAC (1995.): Official methods of analysis (16 ${ }^{\text {th }}$ ed.). Washington, DC: Association of Official Analytical Chemists.

AOAC (2002.): Official methods of analysis (1 $7^{\text {th }}$ ed.). Washington, DC: Association of Official Analytical Chemists.

AYAZ, F.A., KUCUKISLAMOGLU, M., REUNANEN, M. (2000.): Sugar, nonvolatile and phenolic acids composition of strawberry tree (Arbutus unedo L. var. ellipsoidea) Fruits. Journal of Food Composition and Analysis. 13: 171177.

BARROS, L., CARVALHO, A.M., MORAIS, J., FERREIRA, I.C.F.R. (2010.): Strawberry-tree, blackthorn and rose fruits: detailed characterization in nutrients and phytochemicals with antioxidant properties. Food Chemistry. 120: $247-254$. 
Jana Šic Žlabur i sur.: Funkcionalna vrijednost i nutritivni potencijal proizvoda planike (Arbutus unedo L.)

BOOTH, V.K. (1957.): Carotene, its determination in biological materials. Heffer and Sons Ltd, Cambridge, UK

FERREIRA, S., SANTOS, J., DUARTE, A., DUARTE, A.P., QUEIROZ, J.A. (2012.): Screening of antimicrobial activity of Cistus ladanifer and Arbutus unedo extracts. Natural Product Research. 26: 1558-1560.

GÜNDOĞDU, M., ERCISLI, S., CANAN, I., ORMAN, E., SAMEEULLAH, M., NAEEM, M., BEN AYED, R. (2018.). Diversity in phenolic compounds, biochemical and pomological characteristics of Arbutus unedo fruits. Folia Horticulturae. 30(1): 139-146.

MALEŠ, Ž., ŠARIĆ, D., BOJIĆ, M. (2013.): Quantitative determination of flavonoids and chlorogenic acid in the leaves of Arbutus unedo L. using thin layer chromatography. Journal of Analytical Methods in Chemistry. 2013: 1-4. https://doi.org/10.1155/2013/385473

MALEŠ, Ž., PLAZIBA T, M., VUNDAĆ, V.B., ŽUNTA R, I. (2006.): Qualitative and quantitative analysis of flavonoids of the strawberry tree- Arbutus unedo L. (Ericaceae). Acta Pharmaceutica. 56: 245-250.

MALHEIRO, R., SÁ, O., PEREIRA, E., AGUIAR, C., BAPTISTA, P., PEREIRA, J.A. (2012.): Arbutus unedo L. leaves as source of phytochemicals with bioactive properties. Industrial Crops and Products. 37: 473-478.

MARIOTTO, S., ESPOSITO, E., PAOLA, R.D., CIAMPA, A., MAZZON, E., PRATI, A.C., DARRA, E., VINCENZI, S., CUCINOTTA, G., CAMINITI, R., SUZUKI, H., CUZZOCREA, S. (2008.): Protective effect of Arbutus unedo aqueous extract in carrageenan-induced lung inflammation in mice. Pharmacological Research. 57: 110-124.

MIGUEL, M.G., FALEIRO, M.L., GUERREIRO, A.C., ANTUNES, M.D. (2014.): Arbutus unedo L.: Chemical and Biological Properties. Molecules. 19: 15799-15823.

MORALES, P., FERREIRA, I.C.F.R., CARVALHO, A.M., FERNÁNDEZRUIZ, V., SÁNCHEZ-MATA, M.C., CÂMARA, M., MORALES, R., TARDIO, J. (2013.). Wild edible fruits as a potential source of phytochemicals with capacity to inhibit lipid peroxidation. European Journal of Lipid Science and Technology. 115: 176-185.

NARODNE NOVINE (2019.): Pravilniku o voćnim džemovima, želeima, marmeladama, pekmezu te zaslađenom kesten pireu. NN 84/2019. 
OLIVEIRA, I., BAPTISTA, P., BENTO, A., PEREIRA, J.A. (2011.): Arbutus unedo L. and its benefits on human health. Journal of Food and Nutrition Research. 50: 73-85.

OUGH, C.S., AMERINE, M.A. (1988.): Methods for Analysis of Musts and Wines. John Wiley and Sons. New York. USA

PALLAUF, K., RIVAS-GONZALO, J.C., DEL CASTILLO, M.D., CANO, M.P., DE PASCUAL-TERESA, S. (2008.): Characterization of the antioxidant composition of strawberry tree (Arbutus unedo L.) fruits. Journal of Food Composition and Analysis. 21: 273-281.

PAVLOVIĆ, D.R., LAKUŠIĆ, B., DOŠLOV-KOKORUŠ, Z., KOVAĆEVIĆ, N. (2009.): Arbutin content and antioxidant activity of some Ericaceae species. Pharmazie. 64: 656-659.

PIMPÃO, R.C., DEW, T., OLIVEIRA, P.B., WILLIAMSON, G., FERREIRA, R.B., SANTOS, C.N. (2013.). Analysis of phenolic compounds in Portuguese wild and commercial berries after multienzyme hydrolysis. Journal of Agricultural and Food Chemistry. 61: 4053-4062.

POTT, D.M., OSORIO, S., VALlARINO, J.G. (2019.): From Central to Specialized Metabolism: An Overview of Some Secondary Compounds Derived From the Primary Metabolism for Their Role in Conferring Nutritional and Organoleptic Characteristics to Fruit. Frontiers in Plant Science. 10: 835. doi: 10.3389/fpls.2019.00835

RE, R., PELleGrini, N., PROTEGGENTE, A., PANNAlA, A., YANG, M., RICE-EVANS, C.A. (1999.): Antioxidant activity applying an improved ABTS radical cation decolorization assay. Free Radical Biology and Medicine. 26(9-10): 1231-1237.

RUIZ-RODRIGUEZ, B.M., MORALES, P., FERNANDEZ-RUIZ, V., SANCHEZ-MATA, M.C., CAMARA, M., DIEZ-MARQUES, C., PARDODE-SANTAYANA, M., MOLINA, M., TARDIO, J. (2011.): Valorization of wild strawberry-tree fruits (Arbutus unedo L.) through nutritional assessment and natural production data. Food Research International. 44: 1244-1253.

SAS/STAT (2010.): SAS Institute. Cary. NC. USA. 
SKENDROVIĆ-BABOJELIĆ, M., BOGDANOVIĆ, S., DLAČIĆ, I., DURALIJA, B., PRGOMET, Ž., PRGOMET, I., ŠIC ŽLABUR, J., VOĆA, S. (2020. Obična planika (Arbutus unedo L.): Biološka, kemijska i gospodarska svojstva. Sveučilište u Zagrebu Agronomski fakultet, Zagreb.

SOUFLEROS, E.H., MYGDALIA, S.A., NATSKOULIS, P. (2005.): Production process and characterization of the traditional Greek fruit distillate "koumaro" by aromatic and mineral composition. Journal of Food Composition and Analysis. 18(7): 699-716.

ŠIC ŽLABUR, J., VOĆA, S., BRNČIĆ, M., RIMAC-BRNČIĆ, S. (2018.): New Trends in Food Technology for Green Recovery of Bioactive Compounds from Plant Materials.U knjizi: Role of Materials Science in Food Bioengineering (Grumezescu, A., Holban, A. M. ur.). London, Elsevier. pp: 136.

ŠIC ŽLABUR, J., VOĆA, S., DOBRIČEVIĆ, N., PLIESTIĆ, S., GALIĆ, A., BORIČEVIĆ, A., BORIĆ, N. (2016.): Ultrasound-assisted extraction of bioactive compounds from lemon balm and peppermint leaves. International Agrophysics. 30 (1): 95-104.

VIDRIH, R., HRIBAR, J., PRGOMET, Ž., ULRICH, N.P. (2013.): The physicochemical properties of strawberry tree (Arbutus unedo L.) fruits. Croatian Journal of Food Science and Technology. 5: 29-33.

\section{Adresa autora - Authors address:}

Jana Šic Žlabur,

Martina Skendrović Babojelić, e-mail: mskendrovic@agr.hr

Ante Galić,

Sandra Voća.

Sveučilište u Zagrebu Agronomski fakultet Zagreb, Svetošimunska cesta 25, 10000 Zagreb 